\title{
Upaya Meningkatkan Perkembangan Kognitii Anak Isia Dini dalam Pembelajaran Pai Melalui Pendekatan Beyond Centers And Circle Time (BCCT)
}

\author{
Asih Wahyuni \\ STKIP Muhammadiyah Sorong
}

Abstract: This paper discusses the improvement of children's cognitive in learning of PAI using BCCT (Beyond Centers and Circle Time) approach. In this approach, the child is stimulated to actively perform the play activities while learning in the learning centers. Center a made based on the needs and development of children. Some centers used include 1) central role play; 2) beam center; and 3) worship centers; 4) preparation center; 5) art creativity center; and 6) centers of natural materials. The results of the study indicate that the BCCT approach improves children's cognitive development with the support of this approach.

Keywords: Children's Cognitive, BCCT Approach, PAI.

\section{Pendahuluan}

Pendidikan merupakan proses pembangunan dan pembentukan manusia melalui tuntutan dan petunjuk yang tepat dan mencakup dalam segala bidang. Pendidikan juga merupakan suatu upaya untuk mema- 
nusiakan manusia. Artinya, melalui proses pendidikan diharapkan terlahir manusia-manusia yang baik. Oleh karena itu untuk mencapai hal tersebut, maka pendidikan sebagai proses pembangunan dan pembentukan manusia harus dimulai sejak dini, atau yang dikenal dengan pendidikan usia pra-sekolah. Adapun tujuan pendidikan pada umumnya adalah menyediakan lingkungan yang memungkinkan anak didik untuk mengembangkan bakat dan kemampuannya secara optimal, sehingga ia dapat mewujudkan dirinya dan berfungsi sepenuhnya sesuai dengan kebutuhan pribadinya dan kebutuhan masyarakat. ${ }^{1}$

Islam senantiasa menyiarkan tanggung jawab yang diemban oleh kedua orang tuanya. Keduanya adalah orang yang paling bertanggung jawab dengan perkembangan anaknya untuk dipersiapkan menjadi anak yang mampu menjaga kehormatan keluarga, agama, dan bangsa. Hal ini karena Islam memandang bahwa anak adalah amanat Allah Swt. yang harus dibimbing, dipelihara, dan diberi pendidikan. Seperti halnya dalam sebuah Hadis yang menjelaskan bahwa setiap bayi dilahirkan dalam keadaan fitrah, orangtuanya yang menjadikan dia Yahudi, Nasrani, atau Majusi. Jadi peran orangtua sangat penting, karena merekalah yang bertanggung jawab atas segala apa yang akan diberikan kepada anaknya. Jika dia dibiasakan untuk melakukan kebaikan, niscaya dia akan tumbuh menjadi orang yang baik. Sebaliknya, jika anak dibiasakan melakukan hal yang buruk dan diterlantarkan tanpa pendidikan dan pengajaran seperti hewan ternak yang dilepas begitu saja dengan bebasnya, niscaya dia akan celaka dan binasa. Oleh karena itu, hendaknya setiap orang tua menjaga anak-anaknya agar mereka selalu dalam kebaikan, mendidik, dan mengajarkan kesederhanaan dan akhlak yang baik, serta menjauhkannya dari pergaulan yang buruk. ${ }^{2}$ Sebagaimana firman Allah dalam Q.S. at-Tahrim ([66]: 6) yang maknanya: "Hai orang-orang yang beriman, peliharalah dirimu dan keluargamu dari api neraka yang bahan bakarnya adalah

1 Utami Munandar, Pengembangan Kreativitas Anak Berbakat (Jakarta: PT Rineka Cipta, 2009), 6.

2 A. Martuti, Mendirikan dan Mengelola PAUD Manajemen Administrasi dan Strategi Pembelajaran (Yogyakarta: Kreasi Wacana, 2010), 4. 
manusia dan batu."3

Ayat ini menjelaskan bahwa untuk sampai ke arah itu (surga) adalah dengan mendidik dan mengajari mereka. Dengan demikian, berarti tugas mengajar, mendidik dan memberikan tuntunan sama artinya dengan upaya untuk meraih surga. Sebaliknya, menelantarkan hal tersebut berarti sama dengan menjerumuskan diri ke dalam neraka. Tidak hanya Allah Swt. yang menekankan kedua orangtua dalam mendidik anak, Rasulullah Saw. Di setiap kesempatan senantiasa berwasiat kepada sahabat juga umatnya agar anak mereka selalu dijaga, dilindungi, dan diperhatikan pendidikannya. Anak adalah sekelompok manusia muda yang usia batasan umurnya tidak selalu sama dalam psikologi perkembangan. Masa muda yang ditandai dengan proses tumbuh kembang yang meliputi aspek fisik, biologis, mental emosional, dan psikologis. Perkembangan mereka, baik yang berupa fisik, psikis, bahasa, kognitif, dan sosial emosionalnya berkembang seiring dengan tingkat usianya.

Adapun di antara kurun waktu yang panjang itu, masa balita merupakan masa emas tumbuh kembang seorang anak, bukan hanya jasmani, tetapi juga jiwa dan kehidupan sosialnya. Salah asah, salah asih dan salah asuh bisa buruk akibatnya. Dengan demikian, pola pengasuhan yang tepat bagi si kecil akan mempengaruhi karakter anak. Asah adalah stimulasi yang diberikan, asih adalah kasih sayang yang diberikan orang tua, sedangkan asuh adalah kecukupan sandang, pangan, papan, dan kesehatan termasuk pendidikan yang diperoleh oleh anak. ${ }^{4}$ Pada masa anak usia lima tahun pertama sering disebut dengan Golden Age karena fisik dan motorik anak berkembang dan bertumbuh dengan cepat, baik perkembangan emosional, intelektual, bahasa, maupun moral (budi pekerti). ${ }^{5} \mathrm{Jadi}$, seorang anak mempunyai potensi yang sangat besar untuk berkembang. Pada usia ini $90 \%$ dari fisik otak anak sudah terbentuk.

3 Departemen Agama RI, Mushaf Qur'an Terjemah (Jakarta: Gema Insani, 2002), 561.

4 Maimunah Hasan, Pendidikan Anak Usia Dini (Yogyakarta: DIVA Press, 2010), 17.

5 Partini, Pengantar Pendidikan Anak Usia Dini (Yogyakarta: Grafino Litera Media, 2010), 2. 
Di masa-masa inilah anak seyogyanya mulai diarahkan karena saat keemasan ini tidak akan datang dua kali. ${ }^{6}$

Jadi, pada lima tahun pertama (masa pra sekolah) merupakan fase yang paling subur, paling panjang, dan paling dominan bagi seorang pendidik untuk menanamkan norma-norma yang mapan dan arahan yang bersih ke dalam jiwa dan sepak terjang anak didiknya. Berbagai kesempatan terbuka lebar untuk sang pendidik, karena pada fase ini semua potensi anak tersedia secara berlimpah dengan adanya fitrah yang bersih, kepolosan yang begitu jernih, kelembutan, dan kelenturan jasmaninya, kalbu yang masih belum tercemari, dan jiwa yang masih belum terkontaminasi. Apabila masa ini dapat dimanfaatkan oleh seorang pendidik secara maksimal dengan sebaik-baiknya, tentu harapan yang besar untuk berhasil akan mudah diraih pada masa mendatang, sehingga kelak sang anak akan tumbuh menjadi seorang pemuda yang tahan dalam menghadapi berbagai macam tantangan. ${ }^{7}$

Dengan melihat betapa pentingnya pendidikan anak sejak dini, maka beragam lembaga pendidikan anak usia dini muncul di Indonesia, misalnya PAUD, TK, KB (Kelompok Bermain), TPA (Tempat Penitipan Anak), dan lembaga lain yang pada dasarnya mengacu pada konsep pendidikan anak usia dini. Untuk mencapai keberhasilan dalam sebuah pendidikan lembaga ini juga memiliki konsep, pola, dan metode pembelajaran yang berbeda, yaitu proses pembelajarannya tidak sama seperti halnya pembelajaran di SD, SMP, ataupun SMA, akan tetapi pembelajarannya lebih mengedepankan bermain sambil belajar.

BCCT adalah pendekatan dalam pembelajaran yang lebih menekankan pada pemusatan anak didik dan eksplorasi lingkungan. Dalam pendekatan ini anak dirangsang untuk secara aktif melakukan kegiatan bermain sambil belajar di sentra-sentra pembelajaran. Seluruh kegiatan pembelajaran berfokus kepada anak sebagai subjek pembelajaran, sedangkan pendidik lebih banyak berperan sebagai motivator dan fasilitator

\footnotetext{
6 Hasan, Pendidikan Anak Usia Dini, 29.

7 Jamaal 'Abdur Rahman, Tahapan Mendidik Anak (Bandung: Irsyad Baitus Salam, 2008), 15.
} 
dengan memberikan pijakan-pijakan. Pijakan yang diberikan sebelum dan sesudah anak bermain dilakukan dalam setting duduk melingkar sehingga dikenal dengan sebutan "saat lingkaran". ${ }^{8}$ Jadi, dari pemaparan di atas dapat diasumsi bahwa pendekatan BCCT dapat meningkatkan perkembangan kognitif anak usia dini. Maka dari itu, tulisan ini mengkaji tentang upaya meningkatkan perkembangan kognitif anak usia dini dalam pembelajaran PAI melalui pendekatan Beyond Centers and Circle Time (BCCT).

\section{Perkembangan Kognitii Anak Usia Dini}

Banyak orang yang menganggap bahwa kata pertumbuhan dan perkembangan sama, akan tetapi pada kenyataannya berbeda. Dalam bukunya yang berjudul Child Development, Elizabeth Bergner Hurlock menyatakan:

Growth refers to quantitative changes increases in size and structure. Not only does the child become larger physically, but the size and structure of the internal organs and the brain increase. As a result of the growth of the brain, the child has a greater capacity for learning, for remembering, and for reasoning. Development refers to qualitative and quantitative change. ${ }^{9}$

Secara sederhana Seifert dan Hoffnung mendefinisikan perkembangan sebagai "Long-term changes in a person's growth, feelings, patterns of thinking, social relationship, and motor skills (proses pertumbuhan yang lama pada seseorang yaitu berupa perubahan perasaan, perubahan pola pikir, perubahan sosial dan perubahan kemampuan motorik). Menurut Reni Akbar Hawadi, perkembangan secara luas menunjuk pada keseluruhan proses perubahan dari potensi yang dimiliki individu dan tampil dalam kualitas kemampuan, sifat, dan ciri-ciri yang baru. Dalam istilah perkembangan juga tercakup konsep usia, yang diawali dari saat pem-

\footnotetext{
8 A. Martuti, Mendirikan dan Mengelola, 78.

9 Elizabeth Bergner Hurlock, Child Development (Japan: McGraw-Hill, 1983), 22-23.
} 
buahan dan berakhir dengan kematian. ${ }^{10}$

Sedangkan perkembangan juga dapat diartikan sebagai the progressive and continuous change in the organism from birth to death (suatu perubahan yang progresif dan kontinu dalam diri individu dari mulai lahir sampai mati). Perkembangan dapat juga diartikan sebagai perubahanperubahan yang dialami oleh individu atau organism menuju tingkat kedewasaannya atau kematangannya yang berlangsung secara sistematis (saling kebergantungan atau saling mempengaruhi antara bagian-bagian organisme dan merupakan suatu kesatuan yang utuh), progresif (bersifat maju, meningkat dan mendalam baik secara kuantitatif maupun kualitatif), dan berkesinambungan (secara beraturan, berurutan bukan secara kebetulan) menyangkut fisik maupun psikis. ${ }^{11}$

Sementara itu, istilah perkembangan, menurut Elizabet B. Hurlock dalam bukunya Psikologi Perkembangan, berarti serangkaian perubahan progresif yang terjadi sebagai akibat dari proses kematangan dan pengalaman yang berproses secara kualitatif. ${ }^{12}$ Dari beberapa pengertian di atas dapat kita lihat bahwa perkembangan adalah bukan hanya sekadar penambahan berat badan maupun tinggi badan seseorang dan terjadi secara kebetulan, akan tetapi perkembangan adalah suatu perubahan yang terjadi pada setiap orang untuk menuju tingkat kematangannya baik menyangkut fisik maupun psikis yang berlangsung secara sistematis dalam waktu yang lama dan berkesinambungan.

Dalam Kamus Besar Bahasa Indonesia, kognitif adalah kegiatan atau proses memperoleh pengetahuan (termasuk kesadaran, perasaan dan sebagainya) atau usaha mengenali sesuatu melalui pengalaman sendiri. ${ }^{13}$ Sementara itu, menurut Chaplin dalam Dictionary of Psycho$\log y$, "Kognitif adalah konsep umum yang mencakup semua bentuk

\footnotetext{
${ }^{10}$ Desmita, Psikologi Perkembangan (Bandung: PT. Remaja Rosdakarya, 2009), 4.

${ }^{11}$ Netty Hartati, et.al., Islam dan Psikologi (Jakarta: PT. Raja Grafindo Persada, 2005), 13.

${ }^{12}$ Eka W. Pramita, Dahsyatnya Otak Anak Usia Emas (Yogyakarta: Interprebook, 2010), 30 .

${ }^{13}$ Mendiknas, Kamus Besar Bahasa Indonesia (Jakarta: Balai Pustaka, 2000), 579.
} 
pengenal, termasuk di dalamnya mengamati, melihat, memperhatikan, memberikan, menyangka, membayangkan, memperkirakan, menduga, dan menilai." ${ }^{14}$ Jadi, kognitif merupakan sebuah istilah umum yang digunakan para psikolog untuk menjelaskan kerja psikologis seseorang, seperti mengamati, berkhayal, berimajinasi, berpikir, menyangka, menduga, menilai, dan mempelajari.

Dapat dikatakan juga bahwa domain kognitif merupakan cara berpikir berlandaskan menggunakan otak. Bloom mengkategorikan domain kognitif kepada enam tingkat. Tingkatan-tingkatan tersebut terdiri dari: pengetahuan (knowledge), pemahaman (comprehension), aplikasi (application), analisis (analysis), sintesis (syinthesis), dan penilaian (evaluation). ${ }^{15}$ Adapun otak memiliki tiga bagian, yaitu (1) batang otak, dikenal sebagai fight atau flight, yaitu apabila anak dalam keadaan tertekan, takut, dan terancam maka hanya batang otaknya yang bekerja, dalam kondisi ini anak tidak dapat belajar dengan baik; (2) limbik, dikenal sebagai "tempat rasa sayang", yaitu apabila anak dalam kondisi aman, nyaman, dan menyenangkan, maka sistem limbik-nya akan bekerja dengan baik dan dalam kondisi ini anak dapat belajar dengan baik; (3) korteks, dikenal sebagai topi berpikir yaitu merupakan pusat berpikir. Jika sistem limbik menerima perasaan nyaman/menyenangkan, maka lapisan ini dapat berfungsi secara baik.

Sesuai dengan teori kognitif Piaget, perkembangan kognitif pada masa awal anak-anak dinamakan tahap praoperasional (preoperational stage), yang berlangsung dari usia 2 hingga 7 tahun. Pada tahap ini konsep dibentuk, penalaran mental muncul, egosentrisme mulai kuat, dan kemudian melemah serta terbentuknya keyakinan terhadap hal yang magis. Tetapi, sebagai "pra" dalam istilah "praoperasional", menunjukan bahwa pada tahap ini teori Piaget difokuskan pada keterbatasan pemikiran anak. Istilah "operasional” menunjukan pada aktivitas mental yang memungkinkan anak untuk memikirkan peristiwa-peristiwa atau

\footnotetext{
${ }^{14}$ Desmita, Psikologi Perkembangan, 103.

${ }^{15}$ Iskandar, Psikologi Pendidikan: Sebuah Orientasi Baru (Ciputat: Gaung Persada Press, 2009), 90.
} 
pengalaman-pengalaman yang dialaminya. ${ }^{16}$

Perkembangan kognitif anak tumbuh dan berkembang seiring dengan tingkat usianya, baik itu kemampuan dalam berpikir, berimajinasi, memilih permainan, dan kemampuan memberikan alasan. Malkus, Feldman dan Gardner menggambarkan perkembangan kognitif sebagai "kapasitas untuk bertumbuh untuk menyampaikan dan menghargai maksud dalam penggunaan dan beberapa sistem simbol yang secara kebetulan ditonjolkan dalam suatu bentuk pengaturan". Sistem simbol ini meliputi kata-kata, gambaran, isyarat, dan angka-angka. Ada beberapa pendapat tentang teori perkembangan manusia, diantaranya, para pendukung teori behavioris memiliki segi pandang bahwa anakanak tumbuh dengan mengumpulkan informasi yang semakin banyak dari hari ke hari. Kebanyakan pengukuran kecerdasan didasarkan pada gagasan untuk mengumpulkan pengetahuan sebanyak-banyaknya. Pandangan yang lain diutarakan oleh para pendukung teori interaksi, atau teori perkembangan yang menguraikan pengetahuan sebagai hal yang membangun dari interaksi anak-anak dengan lingkungan mereka. Menurut sudut pandang ini intelektual dipengaruhi oleh kedua hal, yaitu kematangan dan pengalaman. ${ }^{17}$

Perkembangan kognitif menunjukkan perkembangan dari cara anak berpikir untuk menyelesaikan berbagai masalah, hal ini dapat digunakan sebagai tolak ukur pertumbuhan kecerdasan. Perkembangan kognitif anak usia Taman Kanak-Kanak atau anak dalam fase praoperasional dapat dikenali dengan kemampuan anak untuk melakukan kegiatan representasi mental, yaitu kemampuan untuk menghadirkan benda, objek atau orang dan peristiwa secara mental. ${ }^{18}$ Jadi, dalam hal ini seharusnya anak mampu melakukan percobaan dan penelitian sendiri, sedangkan orang dewasa hanya membimbing dengan menyediakan bahan-bahan

\footnotetext{
${ }^{16}$ Desmita, Psikologi Perkembangan, 130.

${ }^{17}$ Yuliani Nuraini Sujiono, Konsep Dasar Pendidikan Anak Usia Dini (Jakarta: PT. Indeks, 2009), 78.

${ }^{18}$ Dwi Yulianti, Bermain Sambil Belajar Sains di Taman Kanak-Kanak (Jakarta: PT. Indeks, 2010), 15.
} 
yang tepat yang dapat mendukung perkembangan dan pertumbuhan anak baik fisik maupun psikisnya sehingga dapat tumbuh secara optimal, namun yang terpenting adalah bagaimana anak dapat memahami sesuatu, serta anak dapat membangun pengertian dan menemukannya sendiri.

Dalam Permendiknas Nomor 58 Tahun 2009 tentang Standar Pendidikan Anak Usia Dini pasal (1) ayat (1) menjelaskan bahwa standar pendidikan anak usia dini meliputi pendidikan formal dan nonformal yang terdiri atas:

a. Standar tingkat pencapaian perkembangan;

b. Standar pendidik dan tenaga kependidikan;

C. Standar isi, proses dan penilaian, dan;

d. Standar sarana dan prasarana, pengelolaan dan pembiayaan.

Pada dasarnya kemampuan kognitif merupakan kemampuan dalam menggambarkan penguasaan ilmu pengetahuan dan teknologi tiap-tiap orang. Pada dasarnya kemampuan kognitif merupakan hasil belajar. Sebagaimana diketahui bahwa hasil belajar merupakan perpaduan antara faktor pembawaan dan pengaruh lingkungan. ${ }^{19}$ Dengan demikian, faktor-faktor yang dapat mempengaruhi perkembangan kemampuan kognitif anak di antaranya adalah sebagai berikut:

\section{Faktor Keturunan}

Faktor keturunan sangat besar pengaruhnya kepada pembentukan pusat-pusat saraf. Karena faktor keturunan ini merupakan sifat dasar yang dimiliki oleh setiap individu, seperti kita ketahui bahwa janin manusia terjadi dari persatuan benih laki-laki dengan benih telur perempuan. Masing-masing benih ini telah membawa warisan dari pihak ibu dan bapak, yakni dia telah membawa sifat-sifat asli yang dimiliki oleh bapak, yang dipusakai pula bapak dari nenek moyang, begitu juga

\footnotetext{
${ }^{19}$ Sunarto \& B. Agung Hartono, Perkembangan Peserta Didik (Jakarta: PT. Rineka Cipta, 2002), 11.
} 
sifat-sifat asli yang dimiliki oleh ibu beserta sifat-sifat nenek moyang dari pihak ibu itu. ${ }^{20}$ Baik itu sifat-sifat jasmaniah, seperti bentuk wajah, warna kulit, bentuk tubuh, dan bentuk rambut. Maupun sifat-sifat rohaniah, seperti kecerdasan, keberanian, sifat pemurah, sifat dermawan, dan sifat pemarah.

\section{Faktor lingkungan}

Banyak orang yang berbeda dalam mengartikan lingkungan, ada yang menganggap bahwa lingkungan adalah alam sekitar dimana kita hidup, dan ada pula yang mengartikan bahwa lingkungan adalah segala sesuatu yang melingkupi diri dari sejak lahir sampai meninggal dunia. Akan tetapi, sebenarnya lingkungan itu mencakup segala material dan stimulus di dalam dan di luar individu, baik yang bersifat fisiologis, psikologis maupun sosial-kultural. Dengan demikian, lingkungan dapat diartikan secara fisiologis, psikologis, dan secara sosio-kultural. Secara fisiologis, lingkungan meliputi segala kondisi dan material jasmaniah di dalam tubuh seperti gizi, vitamin, air, zat asam, suhu, sistem saraf, peredaran darah, pernafasan, pencernaan makanan, kelenjar-kelenjar indoktin, sel-sel pertumbuhan, dan kesehatan jasmani.

Secara psikologis, lingkungan mencakup segenap stimulasi yang diterima oleh individu mulai sejak dalam konsesi kelahiran sampai mati. Adapun secara sosio-kultural, lingkungan mencakup segenap stimulasi, interaksi dan kondisi dalam hubungannya dengan perlakuan ataupun karya orang lain. Pola hidup keluarga, pergaulan kelompok, pola hidup masyarakat, latihan, belajar, pendidikan, pengajaran, bimbingan, dan penyuluhan adalah termasuk sebagai lingkungan ini. ${ }^{21}$ Jadi dari beberapa pengertian di atas dapat dipahami bahwa lingkungan bukan hanya sekadar alam sekitar di luar diri manusia, akan tetapi lingkungan adalah segala kondisi dan stimulasi yang diterima oleh manusia sejak dalam kandungan sampai meninggal dunia, baik secara fisiologis, psikologis,

\footnotetext{
${ }^{20}$ Mukhtar Yahya, Pertumbuhan Akal dan Memanfaatkan Naluri Kanak-Kanak (Jakarta: Bulan Bintang, 1980), 22.

${ }^{21}$ M. Dalyono, Psikologi Pendidikan (Jakarta: PT. Rineka Cipta, 1997), 129-130.
} 
maupun sosio-kultural. Lingkungan ini sangat besar pengaruhnya kepada pertumbuhan dan perkembangan manusia. Oleh karena itu, seorang pendidik harus memperhitungkan faktor lingkungan pula di samping faktor keturunan. Seorang anak yang telah mewarisi sifat-sifat yang baik belum tentu akan menjadi seorang yang baik, kalau tidak menemui lingkungan yang baik pula bagi pertumbuhan dan perkembangan otaknya. ${ }^{22}$ Jika anak-anak tumbuh dalam lingkungan yang normal, yang setiap harinya dipenuhi dengan berbagai benda dan bangunan dengan orang-orang yang mencintai dan selalu mau berbicara kepada mereka, otaknya akan tumbuh dengan sendirinya. ${ }^{23}$

Taraf kecerdasan anak memang ditentukan oleh berbagai faktor, seperti nutrisi untuk otak, keturunan, lingkungan, cara mendidik anak dan sebagainya. Namun, satu hal yang patut diingat oleh orang tua yang bijak adalah memberi kesempatan seluas-luasnya pada anak untuk berkembang, tentunya tetap dalam pengawasan orang tua. Berbagai penelitian yang dilakukan oleh para pakar anak, menunjukan bahwa proses belajar dan pertumbuhan otak anak selama masa pra sekolah mempunyai hubungan yang kuat dengan keberhasilan mereka di masa depan. ${ }^{24} \mathrm{Hal}$ ini dikarenakan pada masa tersebut pertumbuhan dan perkembangan kecerdasan anak sangat pesat, sehingga pengalaman yang dahulu akan tersimpan lama di ingatannya.

Pada ranah kognitif yang berhubungan dengan hasil belajar intelektual, terdiri dari enam aspek di antaranya:

a. Pengetahuan atau ingatan;

b. Pemahaman;

c. Aplikasi;

\footnotetext{
${ }^{22}$ Mukhtar Yahya, Pertumbuhan Akal, 25.

${ }^{23}$ Kathy Hirsh Psaek, et.al, Einstein Tak Pernah Mneghafal: Bagaimana Sesunguhnya anak-anak Belajar dan Mengapa Mereka Harus Banyak Bermain dan Sedikit Menghafal, terj. Fahmi Yamani (Bandung: PT Mizan Pustaka, 2006), 72.

${ }^{24}$ Prasetyono, Metode Membuat Anak Cerdas Sejak Dini (Yogyakarta: Garai Ilmu, 2008), 11-12.
} 
d. Analisis;

e. Sintesis;

f. Evaluasi.

Anak usia dini adalah kelompok manusia yang berusia 0-6 tahun (di Indonesia berdasarkan Undang-Undang Nomor 20 Tahun 2003 tentang Sistem Pendidikan Nasional). Anak usia dini juga diartikan kelompok anak yang berada dalam proses pertumbuhan dan perkembangan yang bersifat unik, dalam arti memiliki pola pertumbuhan dan perkembangan (koordinasi motorik halus dan kasar), intelegensi (daya pikir, daya cipta, kecerdasan emosi, dan kecerdasn spiritual), sosial emosional (sikap dan perilaku serta agama), bahasa dan komunikasi yang khusus yang sesuai dengan tingkat pertumbuhan dan perkembangan anak. ${ }^{25}$

Adapun Berk, sebagaimana dikutip oleh Yuliani Nuraini, anak usia dini adalah sosok individu yang sedang menjalani suatu proses perkembangan dengan pesat dan fundamental bagi kehidupan selanjutnya. Pada masa ini proses pertumbuhan dan perkembangan dalam berbagai aspek sedang mengalami masa yang cepat dalam rentang perkembangan hidup manusia. Proses pembelajaran sebagai bentuk perlakuan yang diberikan pada anak harus memperhatikan karakteristik yang dimiliki setiap tahapan perkembangan anak. ${ }^{26}$ Usia dini merupakan periode awal yang paling penting dan mendasar sepanjang rentang pertumbuhan dan perkembangan kehidupan manusia. Pada masa usia dini, semua potensi anak berkembang sangat cepat. Fakta yang ditemukan oleh ahli-ahli neurologi, menyatakan bahwa sekitar 50\% kapasitas kecerdasan manusia telah terjadi ketika berusia 4 tahun dan $80 \%$ telah terjadi ketika berusia 8 tahun. ${ }^{27}$

Jadi, dari beberapa pengertian di atas dapat disimpulkan bahwa anak

\footnotetext{
${ }^{25}$ Mansur, Pendidikan Anak Usia Dini dalam Islam (Yogyakarta: Pustaka Pelajar, 2011), 87-88.

${ }^{26}$ Sujiono, Konsep Dasar Pendidikan, 6.

${ }^{27}$ Iva Noorlaila, Panduan Lengkap Mengajar PAUD (Yogyakarta: Pinus Book Publisher, 2010), 17.
} 
usia dini atau anak pra sekolah adalah golongan anak yang berusia 0-6 tahun yang sedang mengalami pertumbuhan dan perkembangan baik secara fisik maupun psikis. Pada masa ini perkembangan dan pertumbuhan berlangsung sangat pesat sehingga masa ini sering disebut masa keemasan (golden age). Masa keemasan (golden age) merupakan masa yang sangat penting bagi tahap pertumbuhan dan perkembangan anak. Pada masa inilah struktur otak balita mengalami perkembangan masa paling pesat. Stimulasi yang diberikan pada masa ini tentu saja akan berpengaruh besar bagi anak untuk memperoleh proses pendidikan. Periode ini adalah tahun-tahun berharga bagi seorang anak untuk mengenali berbagai macam fakta di lingkungannya sebagai stimulasi terhadap perkembangan kepribadian, psikomotor, kognitif, maupun sosialnya. ${ }^{28}$

Untuk itu sebagai seorang pendidik harus bisa memanfaatkan masamasa tersebut dengan sebaik-baiknya. Karena pada fase ini berbagai kesempatan terbuka lebar dengan semua potensi yang telah tersedia. Hal ini dapat diibaratkan bahwa seorang anak adalah bagaikan kertas putih yang kapan saja siap untuk digoreskan tinta diatasnya, apapun pelajaran atau stimulasi yang diberikan akan tertanam dalam dirinya, sehingga ketika sudah dewasa dia tidak akan mudah terpengaruh oleh arus zaman yang tidak baik dan keberhasilan pada masa mendatang akan lebih mudah diraih.

\section{Bermain Sambil Belajar}

Proses pembelajaran anak usia dini adalah melalui bermain, karena bermain merupakan dunia anak. Dengan bermain anak dapat belajar mencapai perkembangan baik perkambangan fisik, emosi, intelektualitas maupun jiwa sosialnya. Saat bermain dapat dilihat perkembangan-perkembangan tersebut, bagaimana anak meningkatkan kemampuan fisiknya, bagaimana perasaannya saat menang atau kalah dalam permainan, bagaimana intelektualnya dalam memanfaatkan benda-benda sebagai mainan, bagaimana pula kematangan sosialnya

\footnotetext{
${ }^{28}$ Pramita, Dahsyatnya Otak Anak, 13.
} 
dalam bermain bersama.

Emmy Budiarti sebagaimana dikutip oleh Iva Noorlaila, menyatakan bahwa bermain adalah suatu kegiatan yang menyenangkan bagi anak, dan bermain adalah suatu kebutuhan yang sudah ada (inhern) dalam diri anak. Dengan demikian, anak dapat mempelajari berbagai keterampilan dengan senang hati, tanpa merasa dipaksa ataupun terpaksa dalam kegiatan bermain..$^{29}$

Seperti pernyataan Mayesty, bagi seorang anak bermain adalah kegiatan yang mereka lakukan sepanjang hari karena bagi anak bermain adalah hidup, dan hidup adalah permainan. Anak usia dini tidak membedakan antara bermain, belajar dan bekerja. Anak-anak umumnya sangat menikmati permainan dan anak terus melakukannya di manapun mereka memiliki kesempatan. Selanjutnya, Piaget dalam buku Yuliani Nuraini Sujiono yang berjudul Konsep Pendidikan Anak Usia Dini mengatakan bahwa bermain adalah suatu kegiatan yang dilakukan berulang-ulang dan menimbulkan kesenangan/kepuasan bagi diri seseorang, sedangkan Parten dalam Mayesty memandang kegiatan bermain sebagai sarana sosoialisasi, diharapkan melalui bermain dapat memberi kesepakatan anak bereksplorasi, menemukan, mengekspresikan perasaan, berkreasi dan belajar secara menyenangkan. Selain itu, kegiatan bermain dapat membantu anak mengenal tentang diri sendiri, dengan siapa anak hidup serta lingkungan tempat anak hidup. ${ }^{30}$

Melalui kegiatan bermain anak diajak untuk bereksplorasi menemukan dan memanfaatkan objek-objek yang dekat dengannya sehingga pembelajaran lebih bermakna. Dengan demikian, pembelajaran harus dirancang sedemikian rupa sehingga melalui bermain anak-anak dapat menemukan konsep dengan suasana yang menyenangkan dan tanpa disadari anak telah belajar sesuatu dalam suasana bermain yang menyenangkan. ${ }^{31}$ Dalam teori surplus energi yang diajukan oleh Friedrich

\footnotetext{
${ }^{29}$ Noorlaila, Panduan Lengkap Mengajar, 37.

${ }^{30}$ Sujiono, Konsep Dasar Pendidikan, 86.

${ }^{31}$ Yulianti, Bermain Sambil Belajar, 25.
} 
Schiller seorang penyair berkebangsaan Jerman pada abad ke-18 dan Herbert Spencer seorang filsuf Inggris dari abad ke-19, kegiatan bermain seperti berlari, melompat, berguling, yang menjadi ciri khas kegiatan anak kecil dan pada anak binatang punya tujuan yang berbeda. Pada manusia serta binatang dengan tingkat evolusi tinggi, bermain terjadi akibat energi yang berlebihan sedangkan pada binatang yang mempunyai tingkat evolusi lebih rendah misalnya serangga, katak, energi tubuh lebih dimanfaatkan untuk mempertahankan hidup karena mereka memiliki keterampilan sangat terbatas sehingga harus banyak menguras tenaga untuk mempertahankan hidup. ${ }^{32}$

Berbeda dengan teori surplus energi, teori istirahat Lazarus menyebutkan bahwa anak bermain agar tenaganya pulih kembali. Misalnya, karena payah belajar, maka anakanak harus beristirahat untuk bermainmain. Teori Karl Gross, teorinya bernama teori biologis. Anak-anak bermain oleh karena anak-anak harus mempersiapkan diri dengan tenaga dan pikirannya untuk masa depannya. Seperti halnya dengan anak-anak binatang yang bermain latihan untuk mencari nafkah, maka anak manusia pun bermain untuk melatih organ-organ jasmani dan rohaninya untuk menghadapi masa depannya. ${ }^{33}$

Pada dasarnya bermain memiliki tujuan utama yakni memelihara perkembangan atau pertumbuhan optimal anak usia dini melalui pendekatan bermain yang kreatif, interaktif dan terintegrasi dengan lingkungan bermain anak. ${ }^{34}$ Sedangkan secara luas bermain bertujuan untuk menumbuhkembangkan potensi-potensi yang telah tersedia sejak lahir, yaitu dengan cara memberikan stimulasi secara maksimal sehingga potensi dapat berkembang secara optimal.

Beberapa manfaat yang dapat dipetik oleh anak melalui aktivitas bermain, sebagai berikut:

a. Permainan yang membutuhkan gerakan dan kecepatan, ber-

\footnotetext{
${ }^{32}$ Martuti, Mendirikan dan Mengelola, 3.

${ }^{33}$ Agoes Soejanto, Psikologi Perkembangan (Jakarta: Rineka Cipta, 2005), 29.

${ }^{34}$ Sujiono, Konsep Dasar Pendidikan, 145.
} 
guna untuk menguatkan otot-otot anak, untuk meningkatkan kemampuan jiwa keingintahuan anak, dan kemampuan anak untuk menggabungkan suatu alat, memisah-misahkannya, dan menyusunnya kembali.

b. Bermain memberikan ruang bagi anak untuk mempelajari banyak hal.

c. Melalui aktivitas bermain, anak belajar membangun hubungan sosial yang baik dengan anak yang lain, dan dia juga belajar saling menolong sesama kawan dan dengan orang yang lebih besar darinya.

d. Melalui bermain, anak mencurahkan energinya untuk membangun dan berkreasi.

e. Melalui bermain, anak dapat mengenali dirinya sendiri dan menemukan batasan bagi kemampuannya yang berbeda dengan kawan-kawannya. Dengan permainan, dia juga dapat mengenali masalah yang dihadapinya dan cara pemecahannya, ${ }^{35}$ serta dapat menemukan dunianya sendiri yang menyenangkan tanpa adanya paksaan.

\section{Implementasi Beyond Centers and Circle Time (BCCT) dalam Pembelajaran Pendidikan Agama Islam}

Bagi anak prasekolah. Dalam penyelenggaraan PAUD seharusnya memperhatikan dan menyesuaikan tahap perkembangan anak. Dengan demikian, model pembelajaran yang memperhatikan hal tersebut adalah pendekatan BCCT. Beyond Centers and Circle Time (BCCT) dipopulerkan oleh tokoh inovasi pendidikan Eropa abad XX, Maria Montesrori (1870-1952) yang menekankan pada kegiatan bermain ketimbang belajar membaca, menulis dan berhitung (Calistung). BCCT yang diterjemahkan menjadi Pendekatan Sentra dan Saat Lingkaran merupakan suatu pendekatan dalam penyelenggaraan pendidikan anak usia dini

\footnotetext{
${ }^{35}$ Akram Misbah Utsman, 25 Kiat Membentuk Anak Hebat, terj. Fitriah Wride (Jakarta: Gema Insani Press, 2005), 89-90.
} 
yang dikembangkan berdasarkan hasil kajian teoretis dan pengalaman empiris. ${ }^{36}$

BCCT adalah suatu pendekatan dalam pembelajaran yang lebih menekankan pada pemusatan anak dan eksplorasi lingkungan. Model pembelajaran BCCT ini harus didasarkan pada prinsip-prinsip dan tahap perkembangan anak yang mengacu pada perkembangan potensi dan minat setiap anak melalui penyediaan lingkungan belajar yang kaya dan memasukan esensi bermain pada setiap pembelajarannya. Esensi bermain yang meliputi perasaan senang, bebas, dan merdeka harus menjiwai setiap pembelajaran. Dalam pendekatan ini anak dirangsang untuk secara aktif melakukan kegiatan bermain sambil belajar di sentra-sentra pembelajaran. Seluruh kegiatan pembelajaran berfokus kepada anak sebagai subjek pembelajaran, sedangkan pendidik lebih banyak berperan sebagai motivator dan fasilitator dengan memberikan pijakan-pijakan. Pijakan yang diberikan sebelum dan sesudah anak bermain dilakukan dalam setting duduk melingkar sehingga dikenal dengan sebutan 'saat lingkaran'. ${ }^{37}$

Ada beberapa pengertian dasar dalam pendekatan sentra main dan saat lingkaran, antara lain pijakan, sentra main dan saat lingkaran. Pijakan adalah dukungan yang berubah-ubah yang disesuaikan dengan perkembangan yang dicapai anak sebagai dasar untuk mencapai perkembangan yang lebih tinggi. ${ }^{38}$ Sentra main adalah zona atau area main anak dengan dilengkapi seperangkat main yang berfungsi sebagai pijakan untuk mendukung perkembangan anak. Saat lingkaran adalah saat dimana pendidik duduk bersama anak-anak dengan posisi melingkar untuk memberikan pijakan kepada anak apa-apa yang akan dilakukan sebelum dan sesudah main. ${ }^{39}$

Jadi, BCCT dapat diartikan adalah suatu pendekatan metode dalam

\footnotetext{
${ }^{36}$ Martuti, Mendirikan dan Mengelola, 77.

${ }^{37}$ Ibid., 78.

${ }^{38}$ Ibid., 79.

${ }^{39}$ Noorlaila, Panduan Lengkap Mengajar, 72.
} 
pembelajaran pada anak usia dini yang diperkaya dengan mainan-mainan yang digunakan sebagai dukungan untuk membantu perkembangan anak lebih tinggi. Dalam pendekatan BCCT proses pembelajaran dikembangkan di sentra-sentra. Sentra dibuat berdasarkan kebutuhan dan perkembangan anak, bisa jadi sentra-sentra yang diterapkan di setiap lembaga tidak sama. Hal ini dikarenakan adanya kebutuhan yang berbeda di setiap lembaga. Di bawah ini terdapat beberapa macam sentra yang dapat diterapkan, di antaranya:

a. Sentra Main Peran

Tempat bermain sambil belajar, dimana anak dapat mengembangkan daya ingat, berimajinasi, berekspresi, dan bereksplorasi. Penekanan pada sentra ini adalah terletak pada bagaimana anak mengeksplorasikan diri sebaik-baiknya. Tujuan pada sentra ini adalah agar anak dapat bersosialisasi dan berinteraksi dengan temannya.

b. Sentra Balok

Di sentra ini anak dapat memilih balok-balok yang telah disediakan sesuai keinginannya. Penekanan pada sentra ini adalah bagaimana anak berimajinasi dan berkreasi dalam menata balokbalok sehingga membentuk seperti bangunan asli. Tujuan pada sentra ini adalah agar anak dapat mengenal tipologi, bentuk dan ruang.

c. Sentra Ibadah

Pada sentra ini difasilitasi dengan kegiatan bermain yang difokuskan pada kegiatan keagamaan, seperti tata cara shalat, tata cara wudlu, dan menghafal surat-surat pendek. Penekanan pada sentra ini adalah penanaman nilai-nilai agama Islam pada anak. Tujuan pada sentra ini adalah agar anak terbiasa dalam melaksanakan ibadah dengan baik dan berakhlak mulia.

d. Sentra Persiapan

Tempat bermain sambil belajar untuk mengembangkan pengalaman keaksaraan. Penekanan pada sentra ini adalah 
bagaimana supaya anak dapat membaca, menulis, dan berhitung. Tujuannya adalah agar anak dapat berpikir teratur, senang membaca, menulis dan berhitung.

e. Sentra Seni dan Kreativitas

Pada sentra ini difasilitasi alat-alat musik dan alat-alat seni lainnya. Penekanan pada sentra ini adalah menstimulasi sensor motorik anak, yaitu dapat dilihat bagaimana anak dapat mengekspresikan dirinya melalui irama, tarian, nyanyian dan gerak lagu. Tujuannya agar anak dapat berpikir secara kreatif dan sensor motorik berkembang dengan baik.

f. Sentra Bahan Alam

Tempat bermain sambil belajar untuk mengembangkan kecerdasan penelitian anak dengan melalui pemanfaatan bahanbahan yang ada dilingkungan sekitar, seperti daun-daunan, pasir, tanah, air dan tanaman. Tujuan pada sentra ini adalah anak dapat menemukan konsep sendiri dan bersosialisasi terhadap lingkungannya.

Dalam proses penerapan pembelajaran BCCT ini digunakanlah empat jenis pijakan untuk mendukung perkembangan anak, antara lain:

a. Pijakan Lingkungan Main. Pada pijakan ini sebelum anak datang, terlebih dahulu pendidik (orang tua) menyiapkan serta menata alat dan bahan main sesuai dengan rencana dan jadwal kegiatan yang telah disusun.

b. Pijakan Sebelum Main. Pada piajkan ini pendidik atau orang tua dan anak melingkar, pendidik memberi salam dan menanyakan kabar anak-anak, mengabsen dan meminta anak secara bergilir untuk memimpin doa. Selanjutnya pendidik menyampaikan tema hari itu dan dikaitkan dengan kehidupan anak, pendidik membacakan cerita yang ada kaitannya dengan tema dan menanyakan isi cerita tersebut kepada anak, kemudian mengaitkan isi cerita dengan kegiatan bermain yang dilakukan anak 
dan mengenalkan anak semua tempat dan alat main yang sudah disiapkan. Langkah selanjutnya pendidik menyampaikan aturan main (digali dari anak), mempresentasikan anak memilih teman main dan mainan, cara menggunakan alat-alat tersebut, kapan memulai dan kapan mengakhiri serta merapikan kembali alat main yang sudah digunakan, setelah itu pendidik mempersilahkan anak bermain. ${ }^{40}$

c. Pijakan Selama Main. Pada pijakan ini pendidik berkeliling diantara anak-anak yang sedang bermain, memberi contoh bagi yang belum bisa menggunakan alat main, memberi dukungan dengan pertanyaan positif yang ada kaitannya dengan pekerjaan yang dilakukan anak, memberi bantuan jika dibutuhkan, mencatat apa yang dilakukan anak baik jenis main maupun tahap perkembangannya, dan mengumpulkan hasil kerja anak dengan terlebih dahulu mencatat nama dan tanggal. Bila waktu tinggal 5 menit pemdidik memberitahukan kepada anak untuk bersiap siap menyelesaikan kegiatan mainnya.

d. Pijakan Setelah Main. Pada pijakan ini pendidik memberitahukan kepada anak bahwa sudah saatnya bagi mereka untuk membereskan alat dan bahan yang sudah digunakan, jadi anak turut dilibatkan. Alat dan bahan diatur dan ditata kembali sesuai jenis dan tempatnya. Setelah itu anak kembali duduk dalam lingkaran. Setelah itu pendidik menanyakan kepada setiap anak kegiatan main yang dilakukan (recalling) guna melatih daya ingat anak dan melatih anak mengemukakan gagasan dan pengalaman mainnya (memperluas perbendaharaan kata anak). ${ }^{41}$

e. Tujuan Pendidikan Islam. Adapun tujuan pendidikan agama Islam pada dasarnya identik dengan tujuan hidup manusia. Secara umum tujuan pendidikan agama Islam adalah arah yang diharapkan setelah subyek didik mengalami perubahan proses

\footnotetext{
${ }^{40}$ Ibid., 71.

${ }^{41}$ Martuti, Mendirikan dan Mengelola, 80-81.
} 
pendidikan, baik pada tingkah laku individu dan kehidupan pribadinya maupun kehidupan masyarakat dan alam sekitar. Ali Asyraf mengatakan bahwa pendidikan agama Islam bertujuan menimbulkan pertumbuhan yang seimbang dari kepribadian total manusia melalui latihan spiritual, intelektual, rasional, perasaan, dan kepekaan tubuh manusia. Pada pernyataan tersebut, terkesan bahwa tujuan pendidikan Islam adalah berusaha untuk menciptakan pertumbuhan dan perkembangan yang seimbang antara semua potensi jiwa manusia, yaitu menyelaraskan fungsi fisik, akal dan perasaan atau daya spiritual manusia untuk menjadi baik yang pada akhirnya membawa manusia tersebut sempurna dalam hidupnya. ${ }^{42}$

\section{Penutup}

Secara umum pendidikan agama Islam bertujuan untuk meningkatkan keimanan, pemahaman, penghayatan, dan pengalaman peserta didik tentang agama Islam, sehingga menjadi manusia muslim yang beriman dan bertakwa kepada Allah SWT serta berakhlak mulia dalam kehidupan pribadi, bermasyarakat, berbangsa dan bernegara. Dari tujuan tersebut dapat ditarik beberapa dimensi yang hendak ditingkatkan dan dituju oleh kegiatan pembelajaran pendidikan agama Islam, yaitu (1) dimensi keimanan peserta didik terhadap ajaran agama Islam; (2) dimensi pemahaman atau penalaran (intelektual) serta keilmuan peserta didik terhadap ajaran agama Islam; (3) dimensi penghayatan atau pengalaman batin yang dirasakan peserta didik dalam menjalankan ajaran Islam; dan (4) dimensi pengamalannya, dalam arti bagaimana ajaran Islam yang telah diimani, dipahami dan dihayati atau diinternalisasi oleh peserta didik itu mampu menumbuhkan motivasi dalam dirinya untuk menggerakan, mengamalkan, dan mentaati ajaran agama dan nilainilanya dalam kehidupan pribadi, sebagai manusia yang beriman dan bertakwa kepada Allah Swt., serta mengaktualisasikan dan merelisasi-

\footnotetext{
${ }^{42}$ Ismail SM, Strategi Pembelajaran Agama Islam Berbasis PAIKEM (Semarang: RaSAIL Media Group, 2011), 37.
} 
kannya dalam kehidupan bermasyarakat, berbangsa, dan bernegara. ${ }^{43}$

Sedangkan menurut Muhamad Abdul Qadir Ahmad, tujuan pendidikan agama Islam adalah sebagai berikut:

a. Membina murid-murid untuk beriman kepada Allah, mencintai, mentaati-Nya dan berkepribadian yang mulia.

b. Memperkenalkan hukum-hukum agama dan cara-cara menunaikan ibadah serta membiasakan mereka senang melakukan syiar-syiar agama dan mentaatinya.

c. Memantapkan rasa keagamaan pada siswa-siswa, membiasakan diri berpegang pada akhlak mulia dan membenci akhlak yang rendah.

d. Membina perhatian sisiwa terhadap aspek kesehatan seperti memelihara kebersihan dalam beribadah, belajar, olahraga, makanan bergizi, menjaga kesehatan dan berobat.

e. Membiasakan siswa-siswa bersikap rela, optimis, percaya pada diri sendiri, menguasai emosi, tahan menderita, dan berlaku sabar. $^{44}$

Jadi, dari pemaparan di atas dapat dilihat bahwa inti dari tujuan pendidikan agama Islam adalah agar peserta didik dapat memahami, menghayati, meyakini, dan mengamalkan ajaran agama Islam sehingga menjadi muslim yang beriman bertakwa kepada Allah Swt. dan berakhlak mulia, sesuai dengan tujuan hidupnya yaitu untuk beribadah kepada Allah Swt.

${ }^{43}$ Muhaimin, et.al., Paradigma Pendidikan Islam: Upaya Mengefektifkan Pendidikan di Sekolah (Bandung: PT. Remaja Rosdakarya, 2002), 78.

${ }^{44}$ Muhamad Abdul Qadir Ahmad, Metodologi Pengajaran Agama Islam (Jakarta: PT. Rineka Cipta, 2008), 15-16. 


\section{Daitar Pustaka}

A. Martuti. Mendirikan dan Mengelola PAUD: Manajemen, Administrasi, dan Strategi Pembelajaran. Yogyakarta: Kreasi Wacana, 2010. . Mengelola PAUD. Yogyakarta: Kreasi Wacana, 2008.

Abdul Majid dan Dian Andayani. Pendidikan Agama Islam Berbasis Kompetensi Konsep dan Implementasi Kerikulum 2004. Bandung: PT. Remaja Rosdakarya, 2006.

Ahmad, Muhamad Abdul Qadir. Metodologi Pengajaran Agama Islam. Jakarta: PT Rineka Cipta, 2008.

Arikunto, Suharsimi. Dasar-dasar Evaluasi Pendidikan. Jakarta: Bumi Aksara, 2009. . Penelitian Tindakan. Yogyakarta: Aditya Media, 2010. . Prosedur Penelitian: Suatu Pendekatan Praktik. Jakarta: PT. Rineka Cipta, 2010.

Departemen Agama RI. Mushaf Qur'an Terjemah. Jakarta: Gema Insani, 2002.

Desmita. Psikologi Perkembangan. Bandung: PT. Remaja Rosdakarya, 2009.

E. Mulyasa. Praktik Penelitian Tindakan Kelas. Bandung: PT. Remaja Rosdakarya, 2010.

Fitriyani, Dety. "Pelaksanaan Pembelajaran Pendidikan pada Anak Usia Dini di PGIT Umar bin Khatab Kudus." Skripsi. Fakultas Tarbiyah IAIN Walisongo, 2009.

Hartati, Netty, et.al. Islam dan Psikologi. Jakarta: PT. Raja Grafindo Persada, 2005.

Hasan, Maimunah. Pendidikan Anak Usia Dini. Yogyakarta: DIVA Press, 2010. 
Hurlock, Elizabeth Bergner. Child Development. Japan: McGraw-Hill, 1983.

Iskandar. Psikologi Pendidikan: Sebuah Orientasi Baru. Ciputat: Gaung Persada Press, 2009.

Ismail SM. Strategi Pembelajaran Agama Islam Berbasis PAIKEM. Semarang: RaSAIL Media Group, 2011.

M. Dalyono. Psikologi Pendidikan. Jakarta: PT. Rineka Cipta, 1997.

Mansur. Pendidikan Anak Usia Dini dalam Islam. Yogyakarta: Pustaka Pelajar, 2011.

Masyrikha, Iffah. "Upaya Pengembangan Kurikulum di PAUD Mekar Kecamatan Rembang Kabupaten Rembang." Skripsi. Fakultas Tarbiyah IAIN Walisongo, 2010.

Mendiknas. Kamus Besar Bahasa Indonesia. Jakarta: Balai Pustaka, 2000.

Muhaimin, et.al. Paradigma Pendidikan Islam Upaya Mengefektifkan Pendidikan di Sekolah. Bandung: PT. Remaja Rosdakarya, 2002.

Munandar, Utami. Pengembangan Kreativitas Anak Berbakat. Jakarta: PT. Rineka Cipta, 2009.

Nisrokh. "Model Pembelajaran Pendidikan Aanak Usia Dini di Lembaga PAUD Islam Terpadu Mutiara Hati Babagan Kec. Lasem Kab. Rembang." Skripsi. Fakultas Tarbiyah IAIN Walisongo, 2009.

Noorlaila, Iva. Panduan Lengkap Mengajar PAUD. Yogyakarta: Pinus Book Publisher, 2010.

Partini. Pengantar Pendidikan Anak Usia Dini. Yogyakarta: Grafino Litera Media, 2010.

Pramita, Eka W. Dahsyatnya Otak Anak Usia Emas. Yogyakarta: Interprebook, 2010.

Prasetyono. Metode Membuat Anak Cerdas Sejak Dini. Yogyakarta: Garailmu, 2008.

Psaek, Kathy Hirsh, et.al. Einstein Tak Pernah Mneghafal: Bagaimana 
Sesunguhnya anak-anak Belajar dan Mengapa Mereka Harus Banyak Bermain dan Sedikit Menghafal, terj. Fahmi Yamani. Bandung: PT. Mizan Pustaka, 2006.

Rahman, Jamaal 'Abdur. Tahapan Mendidik Anak. Bandung: Irsyad Baitus Salam, 2008.

S. Margono. Metodologi Penelitian Pendidikan. Jakarta: Rineka Cipta, 2010.

Sangadah, Naelis. "Implementasi Pendekatan Beyond Centers and Circles Time (BCCT) dalam Pengembangan Kreativitas Anak: Studi pada Pendidikan Anak Usia Dini di Al Muna Islamic Preschool Semarang." Skripsi. Fakultas Tarbiyah IAIN Walisongo, 2009.

Setyosari, Punaji. Metode Penelitian Pendidikan. Jakarta: Kencana, 2010.

Soejanto, Agoes. Psikologi Perkembangan. Jakarta: Rineka Cipta, 2005.

Sugiyono. Metode Penelitian Pendidikan: Pendekatan Kuantitatif, Kualitatif, dan R\&D. Bandung: Alfabeta, 2007.

Sujiono, Yuliani Nuraini. Konsep Dasar Pendidikan Anak Usia Dini. Jakarta: PT. Indeks, 2009.

Sukardi. Metodologi Penelitian Tindakan Kompetensi dan Praktiknya. Jakarta: PT. Bumi Aksara, 2009.

Sunarto \& B. Agung Hartono. Perkembangan Peserta Didik. Jakarta: PT. Rineka Cipta, 2002.

Suwarno. Pengantar Umum Pendidikan. Jakarta: Rineka Cipta, 1992.

Utsman, Akram Misbah. 25 Kiat Membentuk Anak Hebat, terj. Fitriah Wride. Jakarta: Gema Insani Press, 2005.

Yahya, Mukhtar. Pertumbuhan Akal dan Memanfaatkan Naluri KanakKanak. Jakarta: Bulan Bintang, 1980.

Yulianti, Dwi. Bermain Sambil Belajar Sains di Taman Kanak-Kanak. Jakarta: PT. Indeks, 2010.

Zuhairini, et.al. Filsafat Pendidikan Islam. Jakarta: Bumi Aksara, 2009. 